\title{
Multi-stage thrusting at the "Penninic Front" in the Western Alps between Mont Blanc and Pelvoux massifs
}

Received: 8 March 2000 / Accepted: 15 November 2000 / Published online: 1 March 2001

(C) Springer-Verlag 2001

\begin{abstract}
The different segments of the tectonic boundary between external (European) and internal (Penninic) units in the Western Alps, the so-called Penninic Front (PF), formed at different times and according to different kinematic scenarios. During a first episode (Eocene), the PF corresponds to a transpressive suture zone between Penninic and European units. North- to NNW-trending stretching lineations, found along internal nappe contacts within the Penninic units, are related to this episode. This subduction zone was sealed by the Priabonian flysch of the Aiguilles d'Arves, a detrital trench formation that formed during the final stages of subduction. During a second episode, starting in mid-Oligocene times, the $\mathrm{PF}$, imaged along the ECORS-CROP profile, acted as a WNW-directed thrust. This thrust, the Roselend Thrust (RT), only partially coincides with the PF. South of Moûtiers, the RT propagates into the Dauphinois units, carrying the former Eocene PF (including the Priabonian flysch) passively in its hangingwall. South of the Pelvoux massif the RT finds its continuation along the "Briançonnais Front", an out-ofsequence thrust behind the Embrunais-Ubaye nappes. On a larger scale, our findings indicate oblique (sinistral) collision within the future Western Alps during the Eocene, followed by westward indentation of the Adriatic block.
\end{abstract}

Keywords Arcuate mountain belts · Thrusting · Western Alps · Penninic Front · Tectonics · Structural geology

S. Ceriani $(\square) \cdot$ B. Fügenschuh $\cdot$ S.M. Schmid Geologisch-Palaeontologisches Institut, Bernoullistr. 32, 4056 Basel, Switzerland

E-mail: Stefano.Ceriani@unibas.ch

\section{Introduction}

A large-scale tectonic contact defines the tectonic boundary between internal Penninic units (derived from the Valaisan, Subbriançonnais, Briançonnais and Piemont-Liguria paleogeographic domains) and the external and less deformed Helvetic and Dauphinois units (European margin) of Switzerland and France respectively. In previous studies this major tectonic contact, which can be traced all around the arc of the Western Alps, was referred to as either the Pennine/ Penninic Front (Merle and Brun 1984; Mosar et al. 1996; Bagnoud et al. 1998) or Pennine/Penninic Frontal thrust (Spencer 1992; Seward and Mancktelow 1994; Bürgisser and Ford 1998).

As seen from Fig. 1, most Penninic units occupy an internal position within the chain (i.e. behind the external massifs), while others are found in a more external position (klippen of the Chablais and the Préalpes Romandes in front of the Mont Blanc massif; Embrunais-Ubaye units between Pelvoux and Argentera massifs). Most authors use the term "Penninic Front" to denote the map trace of a thrust in front of the internal group of Penninic units. The internal Penninic basement and cover nappes underwent a complex tectono-metamorphic history before being finally emplaced onto the external European units during the Oligocene (Merle and Brun 1984; Ricou and Siddans 1986; Tricart 1986; Gély and Bassias 1990; Nicolas et al. 1990; Fügenschuh et al. 1999). The external group of Penninic units comprises cover nappes, already detached from their crystalline substratum during Late Eocene times and finally emplaced onto the European margin at around the Eocene-Oligocene boundary (Merle and Brun 1984; Mosar et al. 1996; Bagnoud et al. 1998). Hence, these cover nappes largely escaped Alpine metamorphism and intense deformation.

In order to avoid ambiguities we will avoid the term "Penninic Front". Instead, we use the term "Pen- 


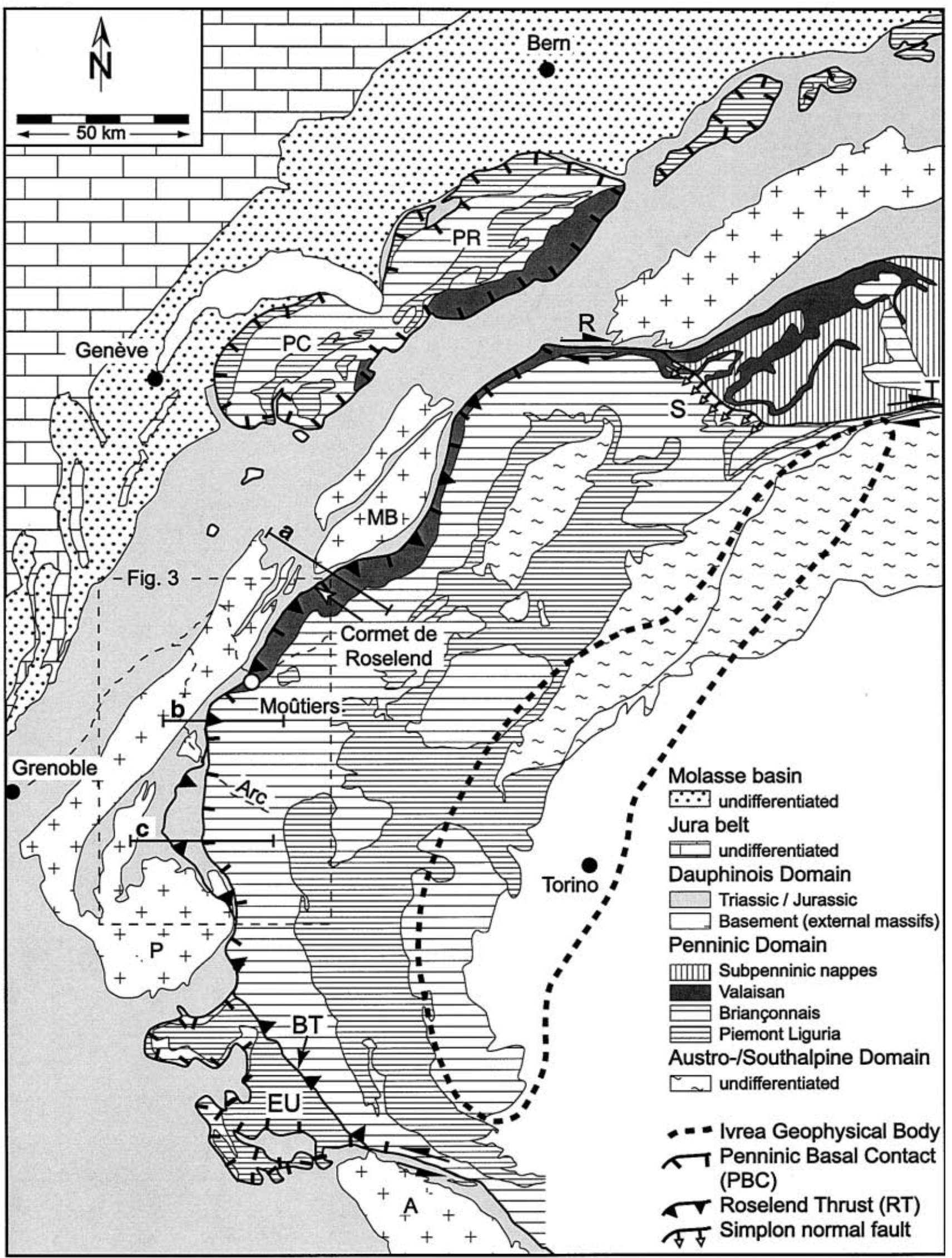


Fig. 1 Tectonic sketch map of the Western Alps, redrawn after Bigi et al. (1983) and Froitzheim et al. (1996). Outlines of the Ivrea geophysical body follow the $>90$ mgal residual Bouguer anomaly due to the Ivrea body as given by Kissling (1980) and Masson et al. (1999). The profile traces, labelled $a, b$ and $c$, refer to Fig. 2, the box indicates the area covered by Fig. 3. A Argentera massif; $B$ Belledonne massif; $B T$ Briançonnais Thrust; $E U$ Embrunais-Ubaye. $M B$ Mont Blanc massif; $P$ Pelvoux massif; $P C$ Préalpes du Chablais; $P R$ Préalpes Romandes; $R$ Rhone line; $S$ Simplon line; $T$ Tonale line

ninic Basal Contact" (PBC) for denoting the map trace of the base of the Penninic units which tectonically overlie the Helvetic-Dauphinois units over the entire area covered by Fig. 1, without attributing a particular kinematic significance (e.g. thrust, strike slip or normal fault) or age to this contact. The term "Roselend Thrust" (RT) will be used for a late-stage WNW-directed thrust, named after the type locality at the Cormet de Roselend. At this locality there is abundant structural (i.e. Fügenschuh et al. 1999) and geophysical (i.e. Roure et al. 1996) evidence for the existence of a first-order WNW-directed thrust of Oligocene to Early Miocene age. Note that the southern continuation of what we will refer to as the Roselend Thrust does not coincide everywhere with the PBC (Fig. 1).

Going along strike from the Mont Blanc to the Argentera massif the geology of the $\mathrm{PBC}$ and adjacent areas changes considerably (Fig. 1). The situation is additionally complicated by late normal faulting in the vicinity of the $\mathrm{PBC}$ (post $5 \mathrm{Ma}$ according to Fügenschuh et al. 1999 north of the Roselend area), and also observed south of the Pelvoux (Sue and Tricart 1999). In spite of this, evidence for WNW-directed thrusting is described along all the three segments described below (Butler et al. 1986; Ricou and Siddans 1986; Tricart 1986; Fry 1989; Gély and Bassias 1990; Nicolas et al. 1990; Spencer 1992; Bürgisser and Ford 1998; Fügenschuh et al. 1999).

A northernmost segment, between Moûtiers and the Mont Blanc massif (Figs. 1, 2a), is taken as the type locality for the definition of the RT. Here, the RT happens to coincide with the position of the PBC (but not further south). In the area of the Cormet de Roselend, field observations (Butler et al. 1986; Gély and Bassias 1990; Fügenschuh et al. 1999) clearly indicate WNW-directed late-stage thrusting of the Valaisan units (i.e. the most external Penninic units in this portion of the chain) onto the Dauphinois. This D3 thrust (Fügenschuh et al. 1999) correlates with one of the key features of the ECORS-CROP seismic traverse (Roure et al. 1996): ESE-dipping seismic reflection bands (Damotte et al. 1990; Thouvenot et al. 1996) down to a depth of about $15 \mathrm{~km}$ (Schmid and Kissling 2000).

Along an intermediate segment, between Moûtiers and the Pelvoux massif (Fig. 1), the southern continu- ation of the RT (Spencer 1992; Fügenschuh et al. 1999) is difficult to follow due to different factors. Firstly, the Valaisan units wedge out and are laterally replaced by the Subbriançonnais and Ultradauphinois units in map view. Secondly, small tectonic units of problematic paleogeographical attribution (i.e. Crève Tête and Niélard units) are present in the area (Bertrand et al. 1996). Finally, the kinematics along the major contacts between these small tectonic units are as yet poorly known. Recent structural work carried out in this area did not establish any unequivocal solution (Spencer 1992; Bertrand et al. 1996; Fügenschuh et al. 1999) for the geographical location and kinematic significance of the PBC in general, nor for the southward continuation of the Roselend Thrust in particular.

Along the southernmost segment, i.e. south of the Pelvoux massif, SW-directed thrust systems predominate (Merle and Brun 1984; Fry 1989; Bürgisser 1999). However, WNW-NNW-directed thrusting has also been described (Merle and Brun 1984; Tricart 1986; Fry 1989; Butler 1992; Bürgisser 1999). The relative timing of these two major thrust systems and their correlation with the Roselend Thrust are still unclear.

This paper focuses on the kinematics along the PBC and the RT north of the Pelvoux massif. Our own data allow us to trace the RT southward till the Vallée de l'Arc (Figs. 1, 2b, c). We will correlate these new data with those of previous authors who worked in this area, and further south (Antoine et al. 1978; Martinez et al. 1979; Antoine et al. 1980; Beach 1981a, 1981b; Bravard et al. 1981; Serre et al. 1985), including our own data from the immediate vicinity of the Pelvoux massif. This will allow us to discuss the multistage tectonic evolution along the "Penninic Front" (RT and PBC) and to address questions related to the formation of the arc of the Western Alps.

\section{A new proposal regarding the geodynamic setting of the "Ultradauphinois" flysch units}

The Valaisan units (Fügenschuh et al. 1999) outcrop only north of Moûtiers where they define the NW front of the Penninic units at the Earth's surface (Fig. 2a). Two different tectonic and paleogeographical units can be distinguished within the Valais domain (Fügenschuh et al. 1999): (1) an internal Valais unit, characterized by remnants of oceanic crust, probably formed during the Early Cretaceous (Stampfli et al. 1998; Fügenschuh et al. 1999) and characterized by basaltic volcanic rocks interbedded with sediments (Versoyen), and (2) external Valais units, containing Triassic and Jurassic pre-rift sediments deposited onto the distal European margin. Both internal and external Valais units are characterized by the presence of Cretaceous to Tertiary? postrift sediments, the so-called trilogy Valaisanne (An- 


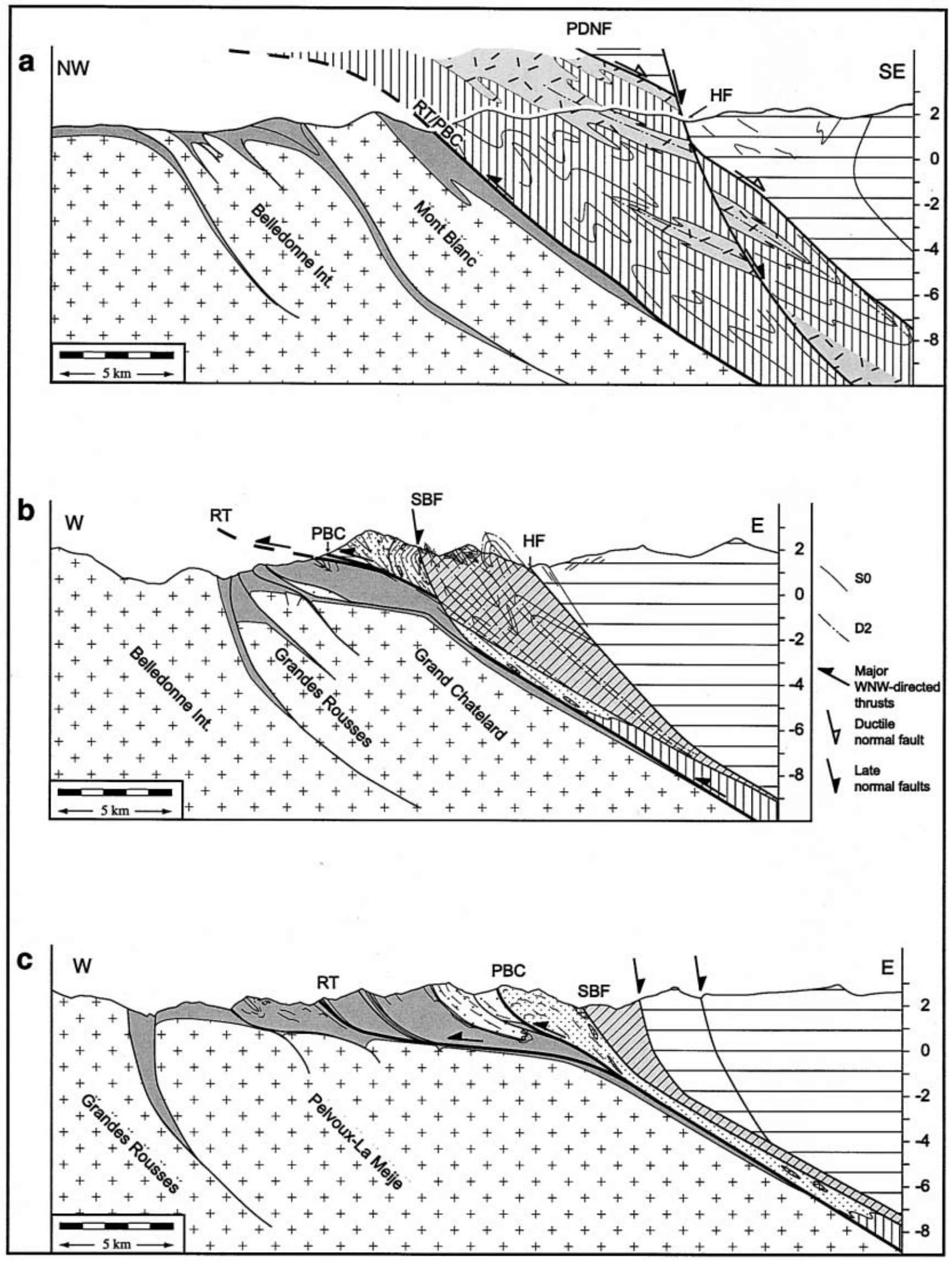


Fig. 2 Profiles across the "Penninic Front" $(R T$ Roselend Thrust; $P B C$ Penninic Basal Contact; $S B F$ Subbriançonnais Front; $H F$ Houiller Front; $P B N F$ Pt. St. Bernard ductile normal fault), signatures as in the legend in Fig. 3, traces indicated in Fig. 1. a Profile parallel to the ECORS-CROP traverse after Fügenschuh et al. (1999). b, c Profiles across the area depicted in Fig. 3, situated further south and partly drawn after Beach (1981a) and Serre et al. (1985)

toine 1971), lying unconformably on top of the older substratum of these two units (Fügenschuh et al. 1999).

Southwards and in map view, the Valaisan units are laterally replaced by two tectonic units which are missing at the present erosional level in the area north of Moûtiers (compare Fig. 2b, c with Fig. 2a): the Subbriançonnais (paleogeographically more internal) and the "Ultradauphinois" flysch (paleogeographically more external). The Subbriançonnais consists of two tectonic units formed by sedimentary cover (Upper Triassic to Oxfordian), detached along Carnian evaporites, namely the Grande Moendaz and the Perron des Encombres units (Barbier 1948; Perez-Postigo 1988; Fügenschuh et al. 1999). The "Ecailles Externes" (Barbier 1948), formed by Cretaceous and Tertiary sediments, were originally considered to represent a third tectonic entity belonging to the Subbriançonnais domain. However, according to Bravard et al. (1981) these "Ecailles Externes" do in fact represent large olistostromes of Subbriançonnais paleogeographical origin, gravitationally emplaced into the youngest strata of the Priabonian flysch of the Cheval Noir unit, generally attributed to the "Ultradauphinois" unit (Fig. 3; Bravard et al. 1981). This "Ultradauphinois" (Barbier 1948) represents the second unit which in map view replaces the Valaisan south of Moûtiers.

The Dauphinois is formed by the external massifs and their sedimentary cover (Carboniferous to Priabonian), largely detached along Upper Triassic to Lower Jurassic dêcollement horizons (Beach 1981a).

Table 1 Correlation table showing the age of the three main deformation phases. D1 and D2 are related to a first episode of sinistral transpression. D3 corresponds to a second episode of
The "Ultradauphinois" is characterized by a thick series of detrital sediments of Priabonian age (flysch $\mathrm{du}$ Cheval Noir and flysch des Aiguilles d'Arves). Because these sediments partly rest on basement and cover rocks of the Dauphinois domain (Figs. 2c, 3; Barbier 1948; Debelmas and Kerckove 1980), the "Ultradauphinois" was classically considered to belong to the European domain, together with the Dauphinois.

However, recent studies demonstrated that the Priabonian flysch of the "Ultradauphinois" has to be subdivided into two different tectonic units (see Figs. 2c and 3), separated by a post-Priabonian thrust (Serre et al. 1985). A lower unit, the Albiez unit (Serre et al. 1985), referred to as the "Aiguilles d'Arves" unit in this contribution, is characterized by a Dauphinois-type substratum of Priabonian flysch. In the upper unit (i.e. the "Cheval-Noir unit"), however, the Priabonian flysch stratigraphically overlies a Briançonnais-type substratum (Martinez 1980; Serre et al. 1985).

South of Moûtiers and north of the Vallée de l'Arc, only the Cheval Noir unit (Barbier 1948; Martinez 1980) is present (Fig. 3). The substratum of the Priabonian flysch is characterized by a condensed stratigraphic series (Permian to Lower Cretaceous), typical of the Briançonnais domain (Martinez et al. 1979). Thick, coarse-grained wild-flysch and breccias unconformably overlie these sediments. At the base of the breccias large olistoliths, kilometric in scale, are present. The olistoliths and most of the clasts of associated breccias are derived from the Penninic units (Antoine et al. 1980). This chaotic base is followed by Priabonian flysch in stratigraphic contact (Antoine et al. 1978). On top of this flysch, a second group of olistoliths of Cretaceous to Lutetian age is found (Bravard et al. 1981). Their sedimentary facies is typical of the Subbriançonnais domain (former "Ecailles Externes" of the Subbriançonnais). The presence of large olistoliths indicates intense tectonic activity near the front of the Penninic units during Priabonian time. Hence, we propose an accretionary wedge scenario for

WNW-directed thrusting, followed by post-5 Ma normal faulting during a third episode (not shown)

\begin{tabular}{|c|c|c|c|c|c|c|c|c|}
\hline & Dauphinois & RT & $\begin{array}{l}\text { "UD" Cheval } \\
\text { Noir }\end{array}$ & SBF & Subbriançonnais & $\mathrm{HF}$ & Zone Houillère & Age \\
\hline D3 & $\begin{array}{l}\text { Main cleavage } \\
\text { and related } \\
\text { folds }\end{array}$ & $\begin{array}{l}\text { Top WNW } \\
\text { thrusting }\end{array}$ & $\begin{array}{l}\text { Open folds } \\
\text { with a poorly } \\
\text { developed axial } \\
\text { plane cleavage }\end{array}$ & Folded & $\begin{array}{l}\text { Open folds with } \\
\text { a poorly } \\
\text { developed axial } \\
\text { plane cleavage }\end{array}$ & Folded & $\begin{array}{l}\text { Open folds with } \\
\text { a poorly } \\
\text { developed axial } \\
\text { plane cleavage }\end{array}$ & $\begin{array}{l}\text { Middle } \\
\text { Oligocene to } \\
\text { Early Miocene }\end{array}$ \\
\hline D2 & - & - & $\begin{array}{l}\text { Main cleavage. } \\
\text { Isoclinal folds }\end{array}$ & $\begin{array}{l}\text { Top N } \\
\text { thrusting }\end{array}$ & $\begin{array}{l}\text { Isoclinal folding } \\
\text { with a strong } \\
\text { axial plane } \\
\text { cleavage }\end{array}$ & $\begin{array}{l}\text { Top NNW } \\
\text { thrusting }\end{array}$ & $\begin{array}{l}\text { Isoclinal folding } \\
\text { with a strong } \\
\text { axial plane } \\
\text { cleavage }\end{array}$ & $\begin{array}{l}\text { Priabonian to } \\
\text { earliest } \\
\text { Oligocene }\end{array}$ \\
\hline D1 & - & - & - & $?$ & $\begin{array}{l}\text { Main cleavage. } \\
\text { Isoclinal folds. } \\
\text { N-S stretching } \\
\text { lineation }\end{array}$ & $?$ & $\begin{array}{l}\text { Main cleavage. } \\
\text { Isoclinal folds }\end{array}$ & $\begin{array}{l}\text { Pre-Priabonian } \\
\text { (Eocene) }\end{array}$ \\
\hline
\end{tabular}




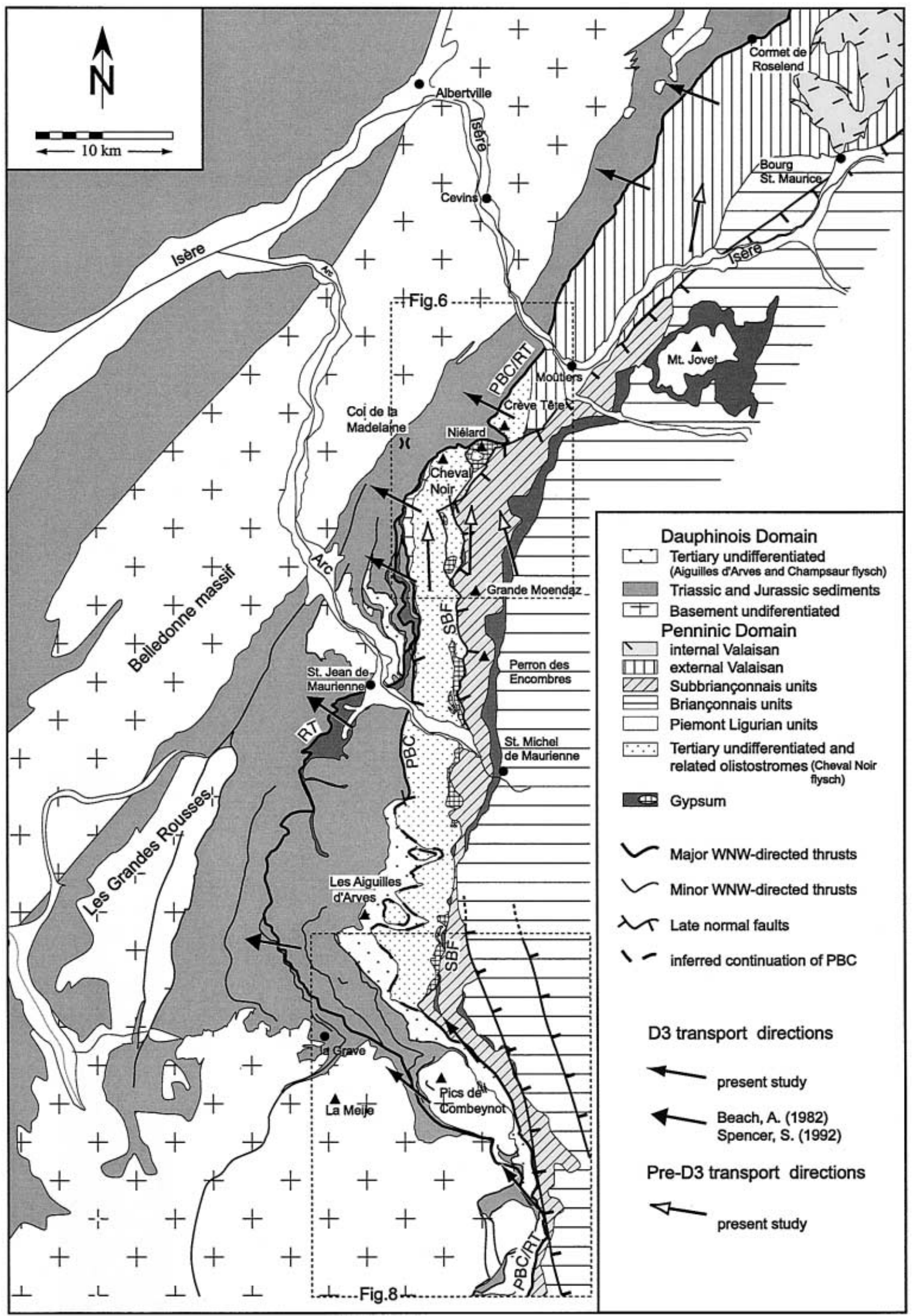


Fig. 3 Tectonic map of the area between Bourg St. Maurice and the Pelvoux massif. The map is mainly based on the "Carte Géologique de la France" (feuille Moûtiers, St. Jean de Maurienne, La Grave and St. Christophe en Oisans; Barféty and Barbier 1976, 1977; Barféty and Pécher 1984; Debelmas 1989). The boxes indicate the area covered by Figs. 6 and 8 respectively. $P B C$ Penninic Basal Contact; $R T$ Roselend Thrust; $S B F$ Subbriançonnais Front. Open arrows indicate the transport direction during D1 and D2 (only found within Penninic units), solid arrows indicate transport direction during D3 along the RT. These arrows are parallel to the local mean azimuth of numerous stretching lineations

the eastern part of this flysch basin during the Late Eocene (see Sinclair 1997 and Fig. 4). Note that the scenario depicted in Fig. 4 indicates sinistral transpression during Eocene times that is coeval with top $\mathrm{N}$ to NNW thrusting and pre-dates younger (i.e. Oligocene) top WNW thrusting along the RT (see discussion below and Table 1).

South of the Arc valley and down to the Combeynot massif a second tectonic unit, containing Priabonian flysch, appears below the Cheval Noir unit: the Aiguilles d'Arves unit (Fig. 3). Here the Priabonian flysch rests on Eocene nummulitic limestones and Globigerina shales. The nummulitic limestone unconformably overlies rocks of the European margin (Dauphinois), the unconformity cutting across all of the Mesozoic series down to the basement rocks of the Combeynot massif. This Eocene unconformity is either due to a previous structuration of the European margin in half grabens (Gillcrist et al. 1987; Grand 1988), and/or to a pre- nummulitic tectonic phase (Debelmas and Kerckhove 1980). A tectonic contact, run- ning through the Priabonian flysch, separates the lower Aiguilles d'Arves unit from the upper Cheval Noir unit (Fig. 2c; Serre et al. 1985).

Consequently, the Priabonian flysch is presently found within two major tectonic units: the internal Cheval Noir unit, floored by a Briançonnais substratum and the external Aiguilles d'Arves unit, floored by a Dauphinois substratum (Serre et al. 1985). This corroborates the idea that the Priabonian flysch has to be considered as a detrital trench formation, related to the final stages of subduction of the Valaisan unit during the Priabonian (Fig. 4) and sealing the former (Eocene) suture zone between Penninic (Valaisan, Subbriançonnais and Briançonnais) and European (Dauphinois) units (Fig. 2b, c). Consequently, there is no need for a separate "Ultradauphinois" tectonic unit and the PBC has to be traced across the Priabonian flysch basin, i.e. between the Aiguilles d'Arves unit and the Cheval Noir unit, along a post-Priabonian thrust (stippled in Fig. 3).

\section{The Roselend Thrust between Cormet de Roselend and Moûtiers}

The results of the structural analysis along the northern segment of the PBC have been described by Fügenschuh et al. (1999) and will only be briefly summarized here. Here, the PBC is marked by the latestage top WNW thrust (see Fig. 5, arrows indicating transport direction in Fig. 3), i.e. the Roselend Thrust (RT). This RT formed under lower greenschist facies conditions and emplaced the previously structured Penninic units onto the Dauphinois across a ductile
Fig. 4 Sketch illustrating the geodynamic setting (oblique collision associated with sinistral transpression) and depositional environment of the Priabonian flysch of the Cheval Noir and the Aiguilles d'Arves units

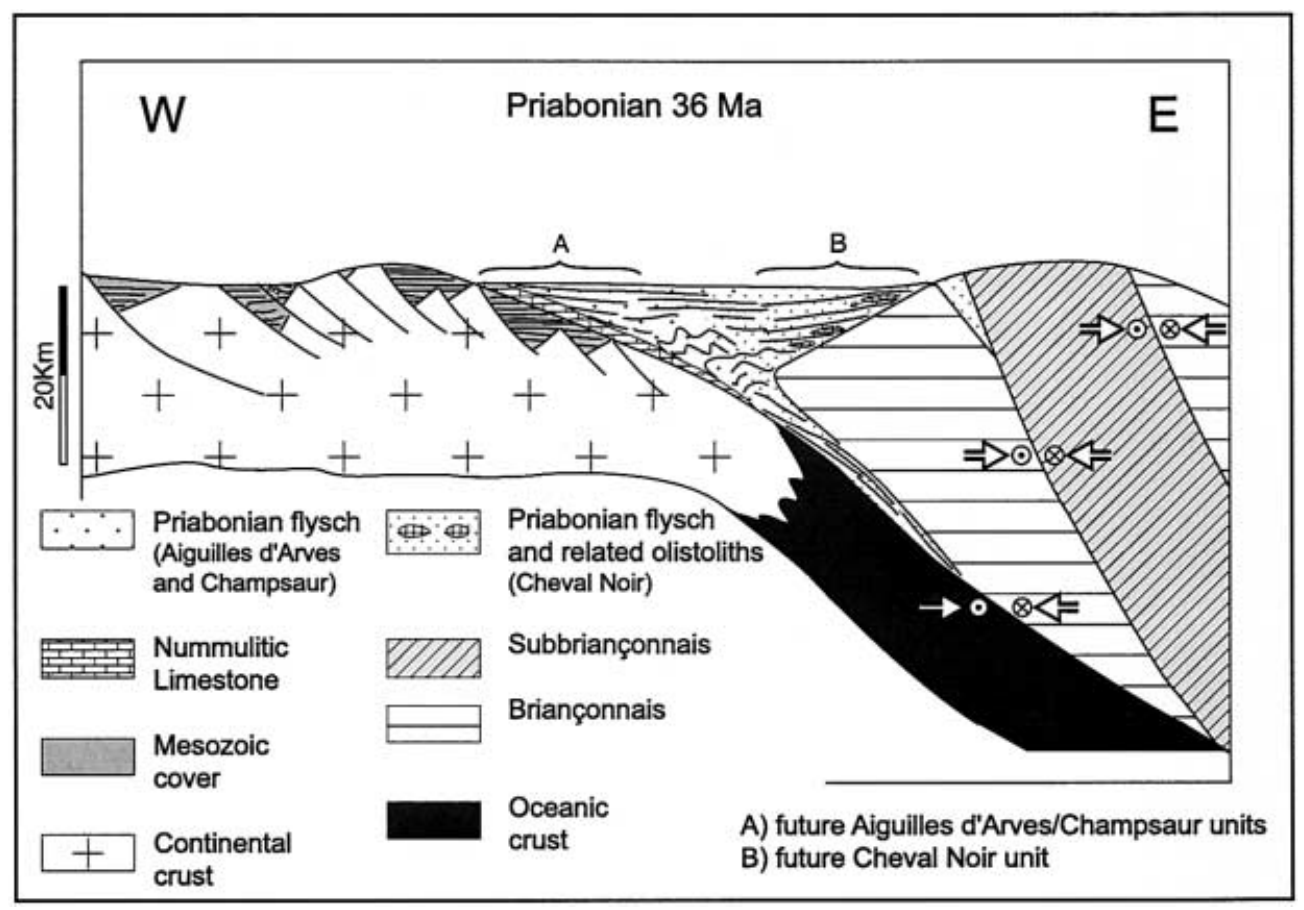




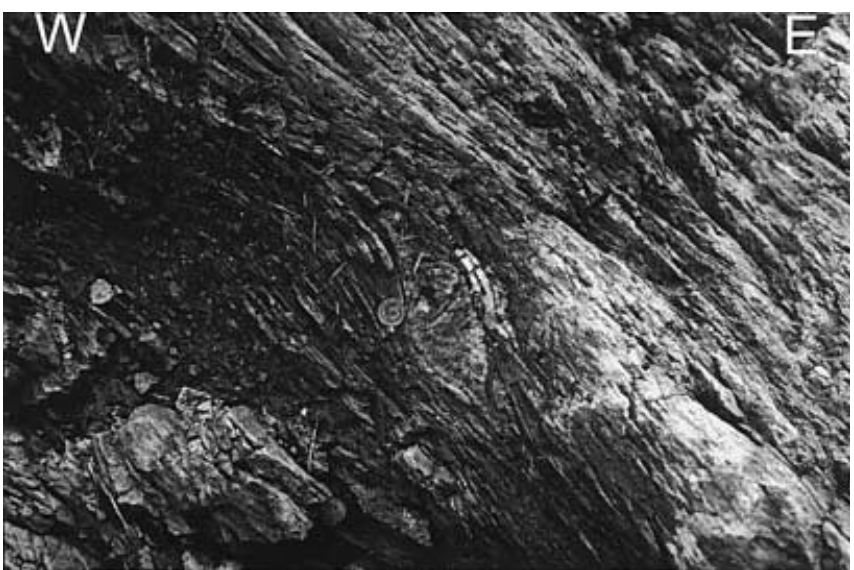

Fig. 5 Asymmetric clast and shear band from the Dauphinois in the immediate footwall of the Roselend Thrust near the Lac de Roselend, indicating top WNW transport along the RT

shear zone, which was active during the late stages of D3 (Fig. 2a). Overprinting relationships clearly demonstrate that thrusting along the RT (and associated D3 folds) post-dates the following earlier multi-stage tectono-metamorphic evolution within the Valaisan units: (1) pre-D1 high-pressure metamorphism (Goffé and Bousquet 1997) followed by (2) top $\mathrm{N}$ to $\mathrm{NNW}$ nappe stacking (D1) and nappe refolding (D2) in a sinistrally transpressive regime corresponding to that of Fig. 4 and (3) by top SE ductile normal faulting at the $\mathrm{W}$ boundary of the zone Houillère (Pt. St. Bernard ductile normal fault, overprinting the Houiller Front, Fig. 2a). The exact age of these pre-D3 deformation events is ill-constrained. However, the age of the third of these pre-D3 (or pre-RT) events, i.e. top SE ductile normal faulting, may be estimated from radiometric dating.

Ar/Ar dating of phengite is available from the Valaisan (Versoyen and Pt. St. Bernhard units) in the footwall of this ductile normal fault in the Pt. St. Bernard pass region (Cannic 1996). The samples yielding "good" and "reasonable" plateaus (Cannic 1996, p. 129) indicate consistent ages around $33 \mathrm{Ma}$. These ages have been interpreted by Cannic as cooling ages. Freeman et al. (1998) performed $\mathrm{Rb}-\mathrm{Sr}$ dating of white micas from sheared rocks of the Pt. St. Bernard unit in the immediate contact to the Zone Houillère from the hangingwall of this normal fault. Freeman et al. (1998) interpreted the $\mathrm{Rb}-\mathrm{Sr}$ white mica ages around $32 \mathrm{Ma}$ in terms of formation ages related to NW-directed thrusting of the zone Houillère over the Valaisan. However, according to our own observations the dated tectonites formed during top SE normal faulting (Fügenschuh et al. 1999). Since the formation ages of Freeman et al. (1998) are compatible with coeval cooling in the footwall of this ductile normal fault, as indicated by the data of Cannic (1996), we suggest that this normal fault was active during the Early Oligocene. This indicates that thrusting along the RT, which post-dates this normal fault, cannot have been active before mid-Oligocene times.

Constraints for the timing of WNW-directed thrusting of Penninic units onto the European foreland are also provided by zircon fission track ages from the external massifs. Complete resetting of old (pre-Tertiary) zircon fission track ages in the external massifs is widespread and related to a metamorphic event. It is likely that this thermal overprinting is related to maximum overburden caused by WNW-directed thrusting. Hence, the age of metamorphism will provide constraints on the timing of this thrusting. The age of metamorphism is best constrained by the data from an area where peak metamorphic conditions were very close to the zircon partial annealing zone, i.e. roughly between 200 and $300^{\circ} \mathrm{C}$ (e.g. Yamada et al. 1995). This is the case for the zircon fission track ages in the Pelvoux area which range from $>100$ to $24 \mathrm{Ma}$ (Seward et al. 1999; Seward, personal communication), while zircon fission track ages in the Belledonne and Mont Blanc massifs (9-16 Ma, Seward and Mancktelow 1994; Fügenschuh et al. 1999) are fully reset, and therefore represent cooling ages. The large variation in ages from the Pelvoux area is most probably due to a variable degree of annealing and resetting. Two samples yielded Late Oligocene apparent zircon fission track ages of 23.9 and $27.5 \mathrm{Ma}$ respectively. Another sample from within the Pelvoux massif (sample P6 from Seward et al. 1999) yielded an apparent age of $38 \mathrm{Ma}$, while ages for the rest of the samples are $>80 \mathrm{Ma}$. Sample P6 is interesting in so far as it fails the $\chi^{2}$ test. It displays a large variation in singlegrain ages. Interestingly, the youngest single-grain ages in this sample are about $24 \mathrm{Ma}$, very similar to the Late Oligocene ages mentioned above. We interpret these ages (24-27.5 Ma) to indicate thermal overprinting which post-dated WNW-directed thrusting by an unknown amount of time of the order of a few million years.

In summary, WNW-directed thrusting along the RT may be estimated to have initiated during middle Oligocene times (post-33 Ma) based on the interpretation of radiometric data. This is in agreement with the age of a Late Oligocene thermal overprint of the Dauphinois, provided by fission track data.

The Roselend Thrust can be safely traced into the area around Moûtiers (Fig. 1), where the southernmost subunit of the Valais unit (i.e. the Quermoz unit) wedges out in map view (see Fig. 6). Fügenschuh et al. (1999) attributed this wedging out to two factors: (1) tectonic omission due to very young (post-5 Ma) post-D3 brittle normal faulting (see the normal fault between the Subbriançonnais and Quermoz units in Figs. 3 and 6) and (2) due to the earlier (pre-RT) N to NNW thrusting in a sinistrally transpressive regime (Fig. 4), indicating that the southward continuation of the Valaisan units is presently buried underneath the Subbriançonnais units. Hence, the southward continuation of the Valais zone has to be looked for in the 
subsurface below the Subbriançonnais units, as depicted in Fig. 2b, c. At the Earth's surface the Priabonian flysch seals the pre-Priabonian Valais suture between the Subbriançonnais and the Dauphinois (see Figs. 2b, c and 4).

\section{The Roselend Thrust between Moûtiers and the Vallée de l'Arc}

Whereas the transition from the Quermoz unit to the Subbriançonnais units in the area of Moûtiers is sharp and marked by a late-stage brittle normal fault (Fig. 6), the transition from the Quermoz to the Cheval Noir unit is less obvious. Two tectonic units of uncertain paleogeographic provenance and tectonic position are present between the Quermoz and Cheval Noir units, i.e. the Crève Tête and the Niélard units.

The Crève Tête unit is largely made up of undated Tertiary flysch. In Fig. 6 we correlate the flysch of the Crève Tête unit with that of the Cheval Noir unit. This correlation is indicated by close lithological similarities between the two units, as pointed out by Martinez (1980). However, the Crève Tête unit cannot simply be considered as the continuation of the Cheval Noir unit in a structural sense. Intense recrystallization, not observed in the sediments forming the Cheval Noir unit, characterizes the rocks of the Crève Tête unit (Martinez 1980). According to Gély (1989), the Crève Tête unit has a metamorphic grade comparable to that of the Quermoz unit (epizone/greenschist facies, i.e. higher than that of the Cheval Noir unit with only anchizone/epizone grade). This suggests that the Crève Tête unit underwent a tectono-metamorphic history similar to that of the Valaisan units. The contact between Crève Tête and Quermoz units (Fig. 6) is marked by a N-S-striking subvertical fault outlined by evaporites (Gély 1989), cut by the younger Roselend Thrust, which can be traced southward along the base of the Crève Tête unit.

Due to erosion (see Fig. 6) the Cheval Noir and the Crève Tête units are spatially separated and their direct mutual contact is not preserved. However, the differences in metamorphic grade suggest the presence of an earlier thrust contact between these two units. Since the RT can be followed continuously from the base of the Crève Tête unit to the base of the Cheval Noir unit, this thrust between Crève Tête and the Cheval Noir units pre-dates the RT.

According to sedimentological evidence (Martinez 1980) and our structural studies, the Niélard unit is considered to be part of the Cheval Noir unit. The pre-Tertiary sediments of the Niélard (Liassic limestone and Jurassic breccias), as well as those of the Valbuche area (basement, Permian and Triassic), represent large olistoliths mainly embedded in the (early Priabonian?) wild-flysch and only partly in the stratigraphically younger (Priabonian) breccias of the Cheval Noir unit (olistoliths mapped out in Fig. 6). In the field the RT can be easily followed from the Quermoz area in the north, crossing the Isère valley into the area south of the Cheval Noir (Fig. 6), because this thrust is always marked by a drastic change in slope of the topography. Here, the RT carries the Crève Tête and Cheval Noir units over the Dauphinois towards the WNW (Fig. 6). We regard these two units as frontal Penninic units because the Priabonian flysch of the Cheval Noir unconformably overlies a Briançonnais-type substratum. Consequently, the RT still coincides with the PBC, i.e. the boundary between Dauphinois and Penninic units.

Analogous to the findings between Moûtiers and the Mont Blanc massif described in the previous section, all major tectonic contacts (except for late-stage brittle normal faulting) between the different Penninic units (i.e. between the Zone Houillère, the Subbriançonnais units and the Cheval Noir unit) pre-date the RT. Furthermore, they were active as top $\mathrm{N}$ thrusts during previous deformation phases (see Fig. 6, Table 1, and Fügenschuh et al. 1999). The Subbriançonnais Front (SBF), separating the Cheval Noir unit from the Subbriançonnais units, and the Houiller Front (HF), separating the Subbriançonnais units from the Houiller unit exhibit N-S-oriented stretching lineations (Fig. 6). Shear sense criteria indicate top $\mathrm{N}$ transport directions for both SBF and HF.

The HF was active as a N-directed sinistrally transpressive thrust during the second deformation phase which affected the Subbriançonnais units as well as the Zone Houillère (D2 in Table 1, to be parallelized with D2 in the Valaisan north of Moûtiers, Fügenschuh et al. 1999). Large isoclinal folds within the Subbriançonnais, mapped out in Fig. 6, are related to this phase of deformation. The D2 schistosity along the $\mathrm{HF}$ is steeply ESE-dipping and stretching lineations plunge to the SSE (see stereoplot in Fig. 6). Asymmetric clasts in anhydrite and gypsum, marking this contact (Fig. 9 in Fügenschuh et al. 1999), indicate $\mathrm{N}$-directed thrusting of the Houiller unit on top of the Subbriançonnais units during sinistral transpression.

Unfortunately the SBF is largely overprinted by very young brittle normal faults (Figs. 3 and 6, Fügenschuh et al. 1999). However, parts of the old D2 contact between the Cheval Noir and Subbriançonnais units are locally still preserved. In the Valbuche area, in the footwall of such a late normal fault (see Fig. 6), a small segment of this older D2 contact is preserved. Here, mylonites and cataclasites mark the contact between Cheval Noir and Subbriançonnais units. The stretching lineations measured in the mylonitic foliation again plunge to the south (stereoplot in Fig. 6). Rotated pyrite clasts and pressure solution phenomena in carbonatic lithologies indicate sinistral transpression with a top to the north transport direction, related to D2 overthrusting of the Subbriançonnais units on top of the Cheval Noir unit (see Fig. 7a, b and Table 1).

In the Cheval Noir unit, this D2 event corresponds to a strong schistosity which is often parallel to bed- 


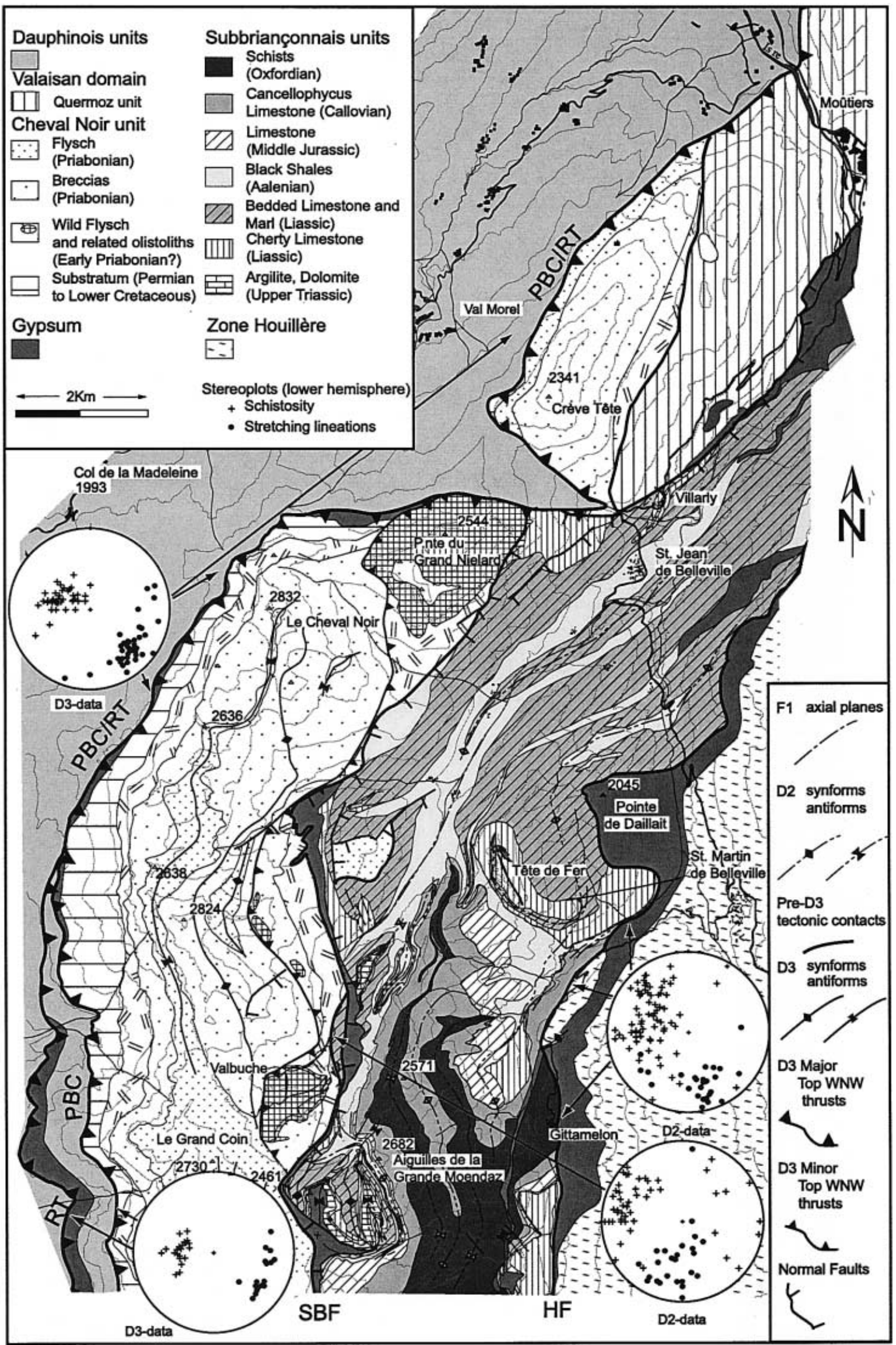


Fig. 6 Geological map of the area south of Moûtiers, between the Roselend Thrust and the Houiller Front respectively. The Crève Tête unit is redrawn after Martinez (1980). Stereoplots give the orientation of the poles to schistosity and of the stretching lineations measured along the major tectonic contacts: the $\mathrm{RT}$, the SBF and the HF. Data from the SBF are measured within syn-D2 sinistral mylonites. No data regarding the latestage normal faults are shown. $H F$ Houiller Front; $P B C$ Penninic Basal Thrust; $R T$ Roselend Thrust; $S B F$ Subbriançonnais Front

Fig. 7 Shear sense indicators from the Subbriançonnais Front in the Valbuche area showing top N (sinistral in micrograph) shear senses during D2. Both samples come from the wild-flysch of the Cheval Noir unit. a Asymmetric pressure solution seams around sigma-clast in a carbonate-rich lithology. b Asymmetric fibrous growth in pyrite pressure fringes in a silica-rich lithology; $C c$ calcite; $C h l$ chlorite; $Q z$ quartz ding. This schistosity is associated with isoclinal folds and with N-S-striking stretching lineations. No older deformation phases were observed within the Cheval Noir unit, indicating that deformation during D1 was confined to the hangingwall of the SBF and did not migrate into the Priabonian flysch basin before D2. This indicates that D1 of the internal Penninic units (Valaisan, Subbriançonnais and Zone Houillère) is pre-Priabonian.

During subsequent W-directed thrusting of the Penninic units onto the Dauphinois along the RT (D3 in Table 1), no major thrusting activity was recorded along the SBF and HF in this area (see Fig. 6 and Table 1). Hence, all the westward displacement was accommodated by the RT, in analogy to what was found north of Moûtiers. In the area of Fig. 6, the RT

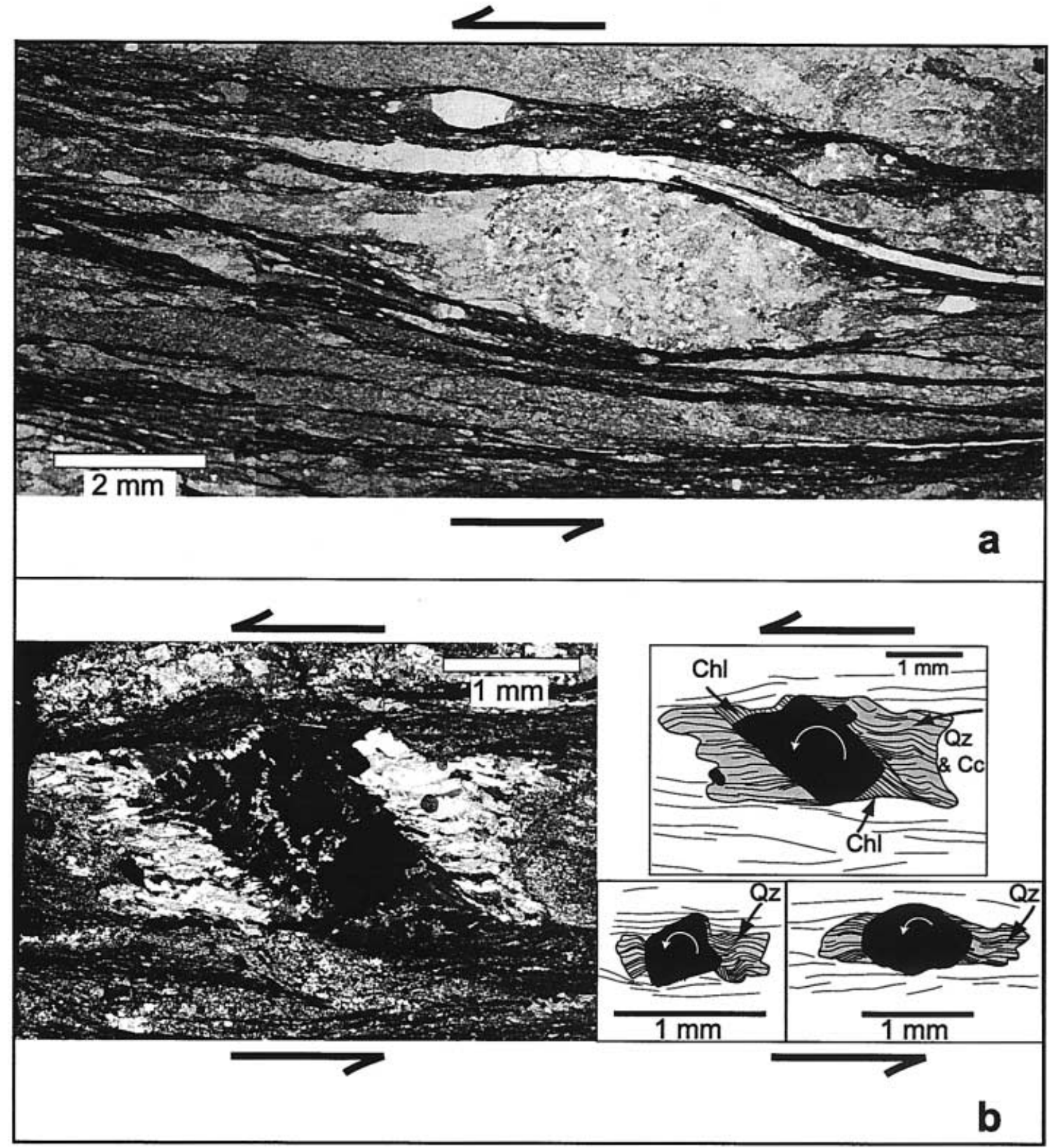


is characterized everywhere by a gently ESE-dipping schistosity. Stretching lineations measured in this schistosity plunge to the ESE (see stereoplot in Fig. 6). Shear sense criteria, such as asymmetric clasts, indicate transport to the WNW. In the Cheval Noir unit large-scale open to chevron type folds, associated with a spaced crenulation cleavage, develop during thrusting activity along the RT (see axial traces in Fig. 6). These folds have an axial plane dipping to the ESE while the fold axes gently plunge towards the SSW. The cleavage related to this tectonic phase, and some related small-scale folds, also overprint the previously formed SBF.

In contrast to the observations made north of Moûtiers, the RT is often marked by the presence of gypsum in this sector. The amount of gypsum along the thrust plane increases from north to south and the gypsum layer becomes more continuous (Fig. 6). Some kilometres south of the Cheval Noir this gypsum horizon marks the contact between the Liassic sediments of the Dauphinois (footwall of the RT) and the Briançonnais substratum of the Cheval Noir unit (hangingwall of the RT). Even further south, however, a second and more external gypsum layer appears (see southern edge of Fig. 6). This second gypsum layer does not mark the contact between the Penninic Cheval Noir and Dauphinois units (hence the PBC) any more but now becomes an intra-Dauphinois thrust that we interpret to represent the southern continuation of the RT (Figs. 2b, 6).

Going to the south until the Arc valley (see Figs. 3, 6) the Dauphinois lithologies between the gypsum layer marking the RT and the PBC form a thick tectonized zone. ESE-dipping schistosity and ESE-plunging stretching lineations characterize this shear zone (see stereoplot in Fig. 6) through its entire thickness. Due to the presence of a large amount of gypsum of Dauphinois origin (see Fig. 3), deformation related to this westward thrusting concentrates in the lower part of the strongly tectonized zone. Immediately north of the Vallée de l'Arc the RT cuts obliquely through a Tertiary syncline, situated in a more external position and within the Dauphinois. Across the Arc valley the RT suddenly cuts further into the Dauphinois foreland towards the southwest and hence definitely no longer follows the border between the Penninic domain and the Dauphinois domain, i.e. the PBC. The PBC is again overprinted by a late normal fault in the Arc valley.

\section{The Roselend Thrust south of the Arc valley}

South of the Arc valley (Fig. 3) the RT carries the Aiguilles d'Arves and Cheval Noir units, including the southern continuation of the PBC, in its hangingwall (Fig. 2b, c). In the area of the Aiguilles d'Arves all the westward-directed displacement within the Dauphinois is taken up by the evaporite horizon following the RT (Beach 1981a, 1981b). East of the RT the Aiguilles d'Arves unit presents a normal stratigraphic series, formed by Jurassic sediments which are unconformably covered by Tertiary sediments (Beach 1981a, 1981b). As shown in Figs. 2b, c and 4, the former Eocene suture between Penninic and Dauphinois units (Valaisan) is hidden underneath the Priabonian flysch deposits of the Cheval Noir and of the Aiguilles d'Arves units. The present-day post-Priabonian tectonic contact between these two different flysch units, described in the Aiguilles d'Arves area by Serre et al. (1985), defines the PBC in this area (Figs. 2c, 3). This portion of the PBC, bifurcating from the RT north of the Vallee de l'Arc, connects with the front of the Subbriançonnais units (SBF) in the Col du Galibier area where the Cheval Noir unit is seen to wedge out (see Figs. 3, 8). According to our own observations south of the Col du Galibier (see Fig. 8), the SBF here forms a WNW-directed thrust, the orientations of schistosity and lineations lying very close to those measured along the RT. This is in contrast to the SBF further to the north, i.e. in the area of Fig. 6, where the SBF formed during earlier top $\mathrm{N}$ movements. This points to a reactivation of the former SBF in the area around the $\mathrm{Col}$ du Galibier during the Oligocene WNW-directed thrusting phase. Further north this W-directed thrust follows the tectonic contact between the Aiguilles d'Arves and Cheval Noir flysch units (PBC in Fig. 3), joining the RT north of the Vallée de l'Arc.

Early sinistral transpression along the SBF, observed in the scarce outcrops of tectonites described previously (i.e. in the Valbuche area further north, see Figs. 6, 7a, b) can be indirectly dated to be ongoing during Late Priabonian times. The youngest strata of the Cheval Noir flysch, situated next to the SBF, are systematically characterized by the presence of large olistostromes of Subbriançonnais origin (Fig. 3) all the way from Moûtiers to the $\mathrm{Col}$ du Galibier area. Their emplacement is interpreted to be related to ongoing Late Eocene tectonic activity along the SBF in this area. During Priabonian times this contact probably represented the internal active margin of the tectonic trench deposits above the subducting European plate and in front of the Penninic units (see Fig. 4). During subsequent westward thrusting along the RT the SBF was not reactivated north of the Col du Galibier. Instead, this contact was overprinted by late brittle normal faulting north of the Vallée de l'Arc (see Fig. 6).

In the Dauphinois domain immediately north of the Pelvoux massif (see Fig. 3) top WNW displacement along the RT is now taken up by a group of anastomosing thrusts planes (Beach 1981a, 1981b). This change in tectonic style is probably due to the wedging out of the gypsum layer present only further north (Beach 1981a). As a consequence, the displacement, largely accommodated by the thick gypsum layer in the north, is distributed along several thrust 
Fig. 8 Structural sketch of the Combeynot area, for geographical location see Fig. 3, signatures as in the legend in Fig. 3 (except for the Dauphinois Mesozoic, see legend of this figure). Stereoplots give the orientation of the poles to schistosity and of the stretching lineations measured along the major tectonic contacts, i.e. the RT and the SBF. $A A^{\prime}$ Trace of the panorama shown in Fig. 9; $P B C$ Penninic Basal Contact; $S B F$ Subbriançonnais Front; $R T$ Roselend Thrust

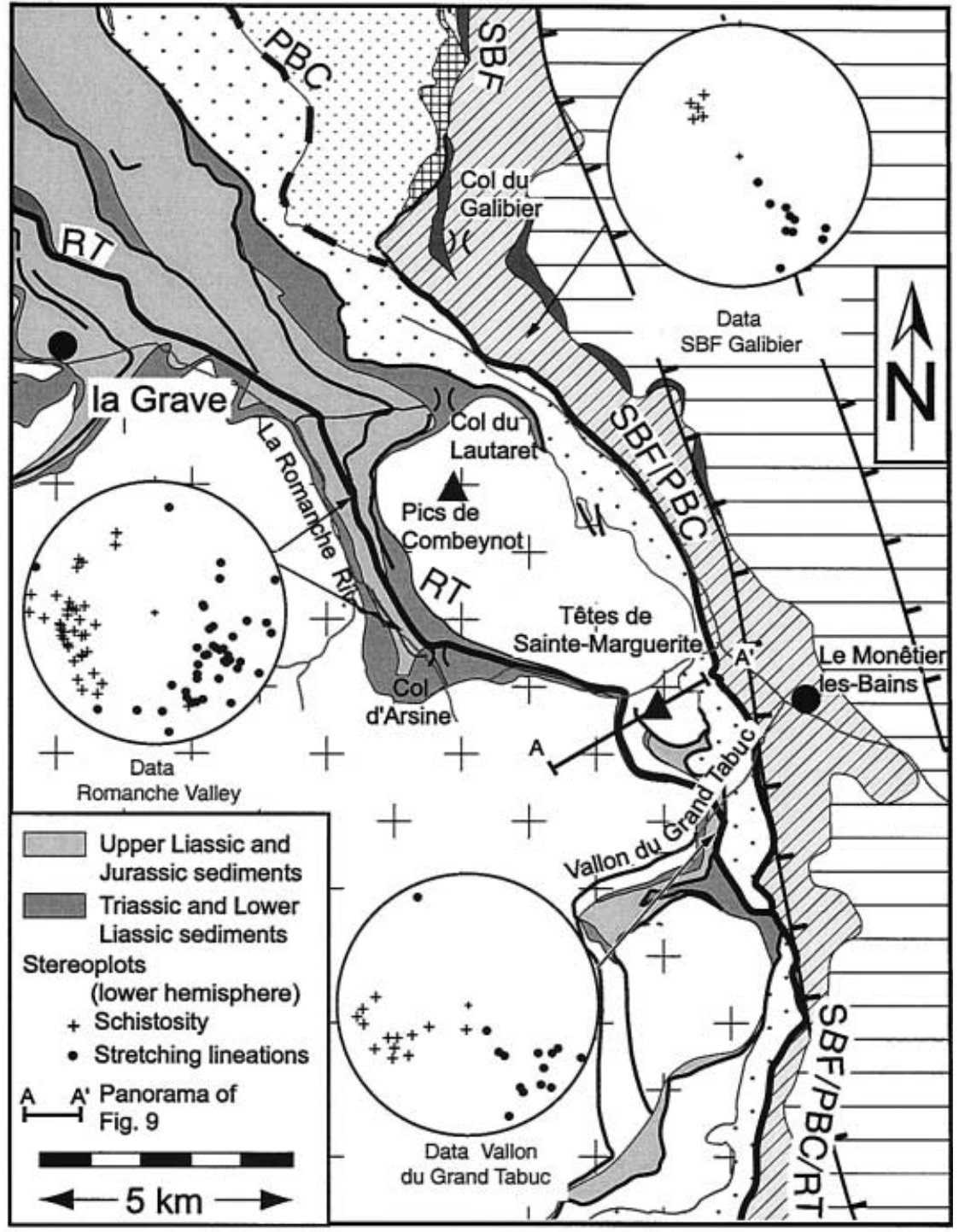

planes further south. It is highly probable that foreland propagation of the RT into the Dauphinois, resulting in its arcuate shape between the Pelvoux massif and the Vallée de l'Arc (Fig. 2), is controlled by the availability of a thick evaporitic horizon which wedges out towards the Pelvoux massif.

Further approaching the Pelvoux massif, WNW-directed displacement again converges into a single shear zone, retreating southeastwards into a narrow corridor of intensely strained Dauphinois sediments between the Combeynot massif and the rest of the Pelvoux massif (Figs. 3, 8). This retreat towards the southeast is probably due to a lateral change into thick-skinned tectonics involving the crystalline basement. Since the southeasternmost part of the Aiguilles d'Arves flysch directly overlies the previously eroded basement of the eastern part of the Combeynot massif (pre-nummulitic tectonic phase, Barbier 1956), the décollement horizons within the Mesozoic cover are no longer available there. Deformation along the RT with the Combeynot massif in its hangingwall and the rest of the Pelvoux massif in its footwall, concentrates within Triassic and Jurassic sediments present between the two blocks of crystalline rocks.

Intense deformation within these sediments, partly forming the cover of the Pelvoux-La Meije and partly that of the Combeynot massif, indicate a transport direction toward the NW to WNW (stretching lineations of Fig. 8 and related shear senses). Since the schistosity turns into a dip to the E to ENE in this part of the RT (as opposed to the dip to the SE observed further north, Fig. 6), the lineations are no longer oriented in a down-dip direction. Kinematically this indicates sinistral transpression along this segment of the RT, acting as a lateral ramp along the northeast margin of the main part of the Pelvoux massif which was significantly uplifted already during pre-Priabonian times due to Cretaceous to Early Eocene "prenummulitic" deformation phases (Barbier 1956; Ford 1996; Bürgisser 1999). 
Fig. 9 Panoramic view of the northern side of the Vallon du Grand Tabuc (see Fig. 8 for location). $P$ Basement of the Pelvoux massif; $M$ Mesozoic between the Pelvoux and the Combeynot massifs; $C$ basement of the Combeynot massif and its Mesozoic cover, partly preserved below the Eocene unconformity; $T$ Tertiary cover of the Combeynot massif, in part directly transgressive on the Combeynot basement; $S B F$ Subbriançonnais Front, coinciding with the Penninic Basal Contact
W

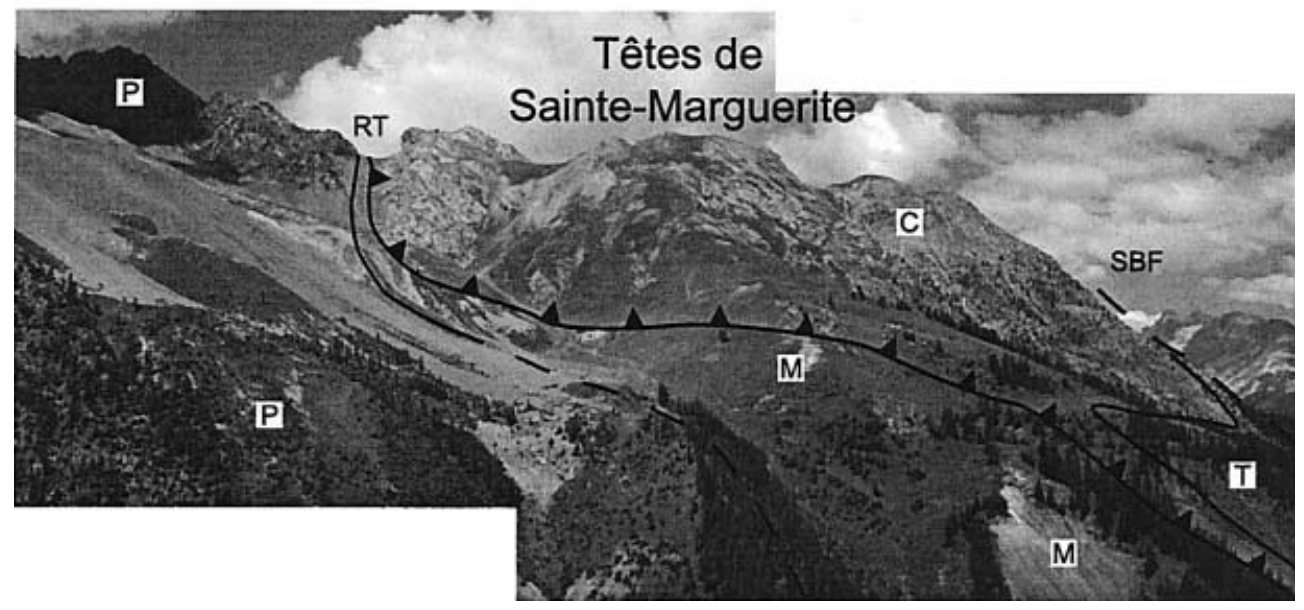

The RT can be followed further to the southeast into the Col d'Arsine area, where this thrust plane is marked by a slice of strongly deformed sediments, still characterized by a strong schistosity dipping to the ENE and lineations plunging to the SE (see Fig. 8). From there, the RT strikes almost E-W for a few kilometres before the thrust plane crosses into the Vallon du Grand Tabuc, immediately west of the Têtes de Sainte Marguerite (see Fig. 9). Here the thrust plane is still marked by the presence of Triassic and Liassic sediments between the crystalline rocks of the Pelvoux and Combeynot massifs.

Eventually the crystalline rocks of the Combeynot massif present in the hangingwall of the RT wedges out (immediately south of the area shown in Fig. 9). As a consequence, the Aiguilles d'Arves Priabonian flysch cover, unconformably overlying the northeast border of the Combeynot basement, now directly overthrusts the Liassic sediments of the cover of the Pelvoux-La Meije massif. Here, the stretching lineations measured in the Tertiary flysch and in the underlying Liassic sediments still indicate a NW- to WNW-directed transport, the schistosity now dipping toward the east. South of the Vallon du Grand Tabuc, the Priabonian flysch of the Aiguilles d'Arves also wedges out. Consequently, the RT joins the PBC again (see Figs. 3, 8), which here is identical with the front of the Subbriançonnais slices. This is supported by the findings of Butler (1992) who describes WNWdirected displacements in the footwall of the Subbriançonnais slices.

Summarizing, in map view the RT exhibits a strongly arcuate shape between the Arc valley and the Pelvoux massif (Fig. 3). At the same time the map trace of the RT departs from that of the PBC, the RT propagating far into the Dauphinois foreland. We suggest that this strongly arcuate geometry is controlled by the presence of a thick Triassic gypsum horizon, which acted as a weak dêcollement horizon and was instrumental in inducing a detachment-controlled salient (Macedo and Marshak 1999) into the foreland. Behind the Pelvoux massif, where this detachment horizon was not available due to pre-Priabonian erosion, the RT re-joins the PBC.

\section{Discussion}

The area along the western front of the Penninic units is the product of a complex tectonic history, ranging from Eocene to recent times. We subdivide this history into three "episodes", each of them being characterized by a particular kinematic scenario. WNW-directed thrusting along the RT (to be correlated with the "Penninic Front" imaged by the ECORS-CROP traverse, Schmid and Kissling 2000) represents only one of these episodes. Until now, relative and absolute timing of the different deformation phases in the studied area were poorly constrained. We first summarize the age constraints provided by radiometric and fission track ages, in combination with structural and sedimentological evidence, and then discuss the kinematic evolution along the "Penninic Front" within a larger scale context of Alpine orogeny.

The oldest deformation phases observed in the area (i.e. D1 and D2 in Table 1 and D1 and D2 as defined by Fügenschuh et al. 1999) may be lumped together into a first episode related to top $\mathrm{N}$ thrusting in the sinistrally transpressive regime depicted in Fig. 4. This episode is linked to $\mathrm{N}-\mathrm{S}$-directed convergence and frontal collision of the Adriatic microplate and the European plate in the Central Alps (Schmid et al. 1996; Schmid and Kissling 2000). Major sinistrally transpressive faults were active at this stage between the different Penninic units (see arrows in Figs. 3 and 6, and Fügenschuh et al. 1999). These results are in contrast with the results of previous structural work carried out in the Subbriançonnais and Cheval Noir units, which only considered orogen-perpendicular radial $\mathrm{W}$-directed thrusting to characterize the entire 
deformation history within these units (Spencer 1992) and within the Western Alps in general (e.g. Malavieille et al. 1984; Platt et al. 1989). Note, however, that the idea of earlier (i.e. Eocene) top $\mathrm{N}$ thrusting in the Western Alps was repeatedly proposed by a number of previous workers (i.e. Barbier 1956; Goguel 1963; Caby 1973; Maury and Ricou 1983; Merle and Brun 1984; Choukroune et al. 1986; Ricou and Siddans 1986).

The first of these deformation phases (i.e. D1), is observed only in the Penninic units, and does not affect the Priabonian flysch of the Cheval Noir unit. Consequently, we propose that this phase is older than the deposition of this flysch, i.e. pre-Priabonian. D1, well developed in the Subbriançonnais and in the Valaisan units, did not affect the Dauphinois domain.

The second deformation phase D2 also developed in a sinistrally transpressive regime, and hence during this first episode. From sedimentological evidence it is clear that syn-D2 $\mathrm{N}$-directed thrusting along the SBF took place during Priabonian time. However, intense D2-related deformation and associated $\mathrm{N}$-S-oriented stretching lineations (see open arrows indicating transport direction in Fig. 3) also affect the rocks of the Cheval Noir unit (i.e. the Priabonian flysch). This suggests that $\mathrm{D} 2$, and hence this sinistrally transpressive regime of the first episode as defined above, was probably active until the Eocene-Oligocene boundary, and that it migrated towards the foreland.

According to Schmid and Kissling (2000) the first episode of N-S-directed head-on collision in the Central Alps, linked to oblique collision in the Western Alps, ended around $35 \mathrm{Ma}$ ago (i.e. near the EoceneOligocene boundary), giving way to a second episode of WNW-directed thrusting in the Western Alps from the Oligocene onwards. Sedimentological and structural data presented in this study confirm such a change in kinematics. Interestingly, this changeover into episode 2 coincides with the transition from flysch- to molasse-type sedimentation in the Alpine foreland of the Central Alps (Sinclair 1997). Ongoing $\mathrm{N}-\mathrm{S}$ convergence in the Central Alps allowed for a continuous changeover from flysch- to molasse-type sedimentation in the Tertiary foreland basin. In the Western Alps, however, flysch sedimentation was abruptly terminated when the Priabonian flysch basin was thrusted piggy-back onto the Dauphinois foreland towards the WNW during the second episode (Fig. 2b, c).

On a larger scale, the first episode is also related to post-Bartonian shortening within the Penninic Romand and Chablais Préalpes and their final N- to NW-directed emplacement onto the external European units (Mosar et al. 1996; Bagnoud et al. 1998). This is compatible with dêcollement of these nappes from their substratum and their first emplacement onto the European foreland (future Helvetic nappes) towards the N to NW. Emplacement of the Embrunais-Ubaye nappes also took place at around the
Eocene-Oligocene boundary (Merle and Brun 1984). Here, early stretching lineations found in the Embrunais-Ubaye nappes (Merle and Brun 1984) indicate a NW-directed transport direction during their first "mise en place" onto the European units, predating later SW-directed transport directions. Vialon et al. (1989) proposed that counterclockwise retro-rotation by about $35^{\circ}$ replaces the paleomagnetic direction of the Triassic rocks of the southern Pelvoux (locality $\mathrm{C}$ in their Fig. 7) parallel to the stable Europe direction. If the same amount of retro-rotation is applied to the Embrunais-Ubaye nappes located immediately south of the Pelvoux massif, this early NW transport corrects to a NNW-directed transport, very much in agreement with the orientations observed further to the north.

After this first episode, the kinematic pattern drastically changes and gives way to WNW-directed thrusts in the Western Alps, i.e. within our working area and in particular along the RT, while the Central Alps still undergo roughly $\mathrm{N}-\mathrm{S}$-oriented shortening (see discussion in Schmid and Kissling 2000). Regarding the timing of this major kinematic change, the stratigraphic evidence (age of the youngest sediments involved in D2, Table 1) clearly shows that NNW-directed thrusting still occurred after the deposition of the Priabonian flysch and hence lasted at least until the Eocene-Oligocene boundary. The initiation of this thrusting is further constrained to mid-Oligocene times by the results of radiometric and fission track dating discussed above. We emphasize that maximum burial and heating of the external Mont Blanc and Belledonne massifs is related to this second episode of WNW-directed thrusting, and that it hence post-dates the internal structuration within the Penninic units formed during top $\mathrm{N}$ shearing. Shortening in the external Dauphinois domain is stratigraphically dated as Early Miocene (Mugnier et al. 1996). It is not clear if this shortening is still kinematically linked to thrusting along the RT (as proposed by Schmid and Kissling 2000), or if Early Miocene deformation in the Dauphinois foreland is the result of the migration of deformation further into the European foreland.

We now discuss the possible kinematic continuation of the structures related to this WNW-directed thrusting along the RT during episode 2 along strike. In view of the time constraints discussed above, the continuation of the RT south of the Pelvoux massif (Fig. 1) has to be looked for in the "Briançonnais Front", as defined by Tricart (1986). This is an Oligocene out-of-sequence thrust, carrying the Briançonnais units on top of the previously (i.e. at around the Eocene-Oligocene boundary) emplaced EmbrunaisUbaye nappes. In map trace, the continuation of the "Briançonnais Front" further to the southeast is found behind the Argentera massif, where it presumably formed by sinistral transpression, provided that the transport direction is still WNW-directed in this area. However, this southernmost area is also affected by 
SW-directed displacements (Merle and Brun 1984; Fry 1989; Bürgisser 1999). At this stage we are unable to integrate this SW-directed thrusting into the kinematic picture evolving from our study in sectors 1 and 2 of the RT (Fig. 1). Possibly, this SW-directed displacement is related to a component of gravitational spreading (as proposed by Platt et al. 1989), or to an anticlockwise rotation of earlier top WNW lineations (Vialon et al 1989).

Northeast and east of our working area the kinematic continuation of the RT has to be looked for along the Oligocene Simplon ductile shear zone (Steck 1990), later overprinted by the more brittle Miocene Simplon-Rhone line (Mancktelow 1985). According to Schmid and Kissling (2000) this dextral shear zone kinematically connects WNW-directed thrusting at the RT to dextral shearing along the Tonale line, Miocene normal faulting across the Simplon fault possibly representing a tensile bridge within this dextral shear zone. Decoupling of the Central Alps from the Southern and Western Alps along the Simplon ductile shear zone and the Rhone-Simplon line explains contemporaneous $\mathrm{N}-\mathrm{S}$ and WNW-ESE shortening in the Central and Western Alps respectively, from mid-Oligocene times onward. The picture which arises from this discussion and from looking at Fig. 1 is one of WNW-directed indentation of the Adriatic block, inducing WNW-directed shortening in the Western Alps, now decoupled from the Central Alps along the Simplon ductile shear zone and the Simplon-Rhone line. Note that the outlines of the Ivrea geophysical body (Fig. 1) predetermine the northern and southern boundary of this indenter, characterized by dextral and sinistral shear (Laubscher 1991) respectively. It is this episode 2 which finally shaped the present-day arc of the Western Alps.

A third episode is characterized by late brittle normal faulting, mapped out in Figs. 3 and 6. This faulting started after $5 \mathrm{Ma}$ ago according to evidence from fission track dating (Fügenschuh et al. 1999). It is still ongoing at the present time in the Penninic core of the Western Alps according to an earthquake analysis by Sue et al. (1999), but not in the Po plain and the European foreland, suggesting that this orogen-perpendicular extension may be caused by gravitational collapse. These normal faults preferentially reactivate some of the thrusts formed during episode 1 and 2 .

We conclude by pointing out that the present-day arcuate shape of the "Penninic Front", and the arc of the Western Alps in general, are the product of a multi-stage evolution characterized by changes in the kinematic evolution and, accordingly, also changes in the stress field. This arcuate shape is not due to oroclinal bending, nor is it related to contemporaneous radial thrusting induced by gravity effects (Platt et al. 1989), although gravity-induced effects might play a role on a more local scale (e.g. Embrunais-Ubaye nappe). Rather it is predetermined by the pre-existing shape of the Ivrea geophysical body in front of the
Adriatic indenter, as proposed by Laubscher (1991). However, this indentation did not start before the Oligocene and overprinted an Eocene regime of sinistral transpression in the area of the Western Alps.

Acknowledgements This study was funded by the Swiss National Science Foundation (projects 20-42132.94, 20-49558.96 and 20-55559.98). The work of Andrea Loprieno substantially contributed towards understanding polyphase thrusting in the Penninic units. The authors also thank S. Fudral and D. Marquer and for fruitful discussions. Serge Fudral was also extremely helpful in providing us with the relevant French literature. Reviews by M. Burkhard and O. Merle are gratefully acknowledged.

\section{References}

Antoine P (1971) La zone des Bréches de Tarentaise entre Bourg-Saint-Maurice (Vallée de l'Isère) et la frontière ItaloSuisse. Travaux Laboratoire Géologique Faculté Sciences Thesis

Antoine P, Barbier R, Bravard C, Gidon M (1978) Les rapports entre le Flysch des Aiguilles d'Arves et le domaine Valaisan au cirque de Valbuche (Savoie). C R Acad Sci Paris 286:1751-1753

Antoine P, Barbier R, Barféty J-C, Debelmas J (1980) Précisions sur la formation détritique de base du flysch des Aiguilles d'Arves entre l'Arc et l'Isère (Savoie). C R Acad Sci Paris 290:1451-1453

Bagnoud A, Wernli R, Sartori M (1998) Découverte de foraminifères planctoniques paléogènes dans la zone de Sion-Courmayeur à Sion (Valais, Suisse). Eclogae Geol Helv 91:421-429

Barbier R (1948) Les zones Ultradauphinois et Subbriançonnaise entre l'Arc et l'Isère. Mémoires pour servir de à l'explication de la carte Géologique détaillee de la France. Thesis, Faculté des sciences de Strasbourg

Barbier R (1956) L'importance de la tectonique "anté nummulitique" dans la zone ultradauphinoise au nord du Pelvoux: la chaîne arvinche. Bull Soc Geol Fr 6:355-370

Barféty J-C, Barbier R (eds) (1976) Carte Géologique de la France feuille La Grave, 1:50000. BRGM

Barféty J-C, Barbier R (eds) (1977) Carte Géologique de la France feuille St. Jean De Maurienne, 1:50000. BRGM

Barféty J-C, Pécher A (eds) (1984) Carte Géologique de la France feuille St. Christophe en Oisans, 1:50000. BRGM

Beach A (1981a) Thrust structures in the eastern Dauphinois Zone (French Alps), north of the Pelvoux Massif. J Struct Geol 3:299-308

Beach A (1981b) Thrust tectonics and cover-basement relations on the northern margin of the Pelvoux massif, French Alps. Eclogae Geol Helv 74:471-479

Beach A (1982) Strain analysis in a cover thrust zone, External French Alps. Tectonophysics 88:333-346

Bertrand JM, Aillères L, Gasquet D, Macaudière J (1996) The Pennine Front zone in Savoie (Western Alps), a review and new interpretations from the zone Houillère Briançonnaise. Eclogae Geol Helv 89:297-320

Bigi G, Cosentino D, Coli M, Parotto M, Sartori R, Scandone P (1983) Structural model of Italy, sheet no.1, 1:500000. CNR Italy

Bravard C, Kerckhove C, Barbier R (1981) Réinterpretation du sommet de la série des Aiguilles d'Arves et de ses rapports avec la zone Subbriançonnaise dans la vallée de l'Arc ( $\mathrm{Sa}-$ voie, Alpes occidentales). C R Acad Sci Paris 292:531-534

Bürgisser J (1999) Deformation in foreland basins of the Western Alps (Pelvoux Massif, SE France); significance for the development of the Alpine arc. PhD Thesis, ETH Zürich 
Bürgisser J, Ford M (1998) Overthrust shear deformation of a foreland basin; structural studies south-east of the Pelvoux massif, SE France. J Struct Geol 20:1455-1475

Butler RWH (1992) Thrust zone kinematics in a basementcover imbricate stack: Eastern Pelvoux massif, French Alps. J Struct Geol 14:29-40

Butler RWH, Matthews S, Parish M (1986) The NW external Alpine thrust belt and its implication for the geometry of the western Alpine Orogene. In: Coward MP, Dietrich D, Park RG (eds) Collision tectonics. Geol Soc Lond Spec Publ 19, pp 245-260

Caby R (1973) Les plis transversaux dans les Alpes occidentales: implication pour la genèse de la chaîne alpine. Bull Soc Geol Fr 7(15):624-634

Cannic S (1996) L'évolution magmatique et tectono-métamorphique du substratum du domaine valaisan (complexe du Versoyen, Alpes occidentales): implications dans l'histoire alpine. PhD Thesis, Grenoble

Choukroune P, Ballèvre M, Cobbold P, Gautier Y, Merle O, Vuichard JP (1986) Deformation and motion in the Western Alpine arc. Tectonics 5:215-226

Damotte B, Nicholich R, Cazes M, Guellec S (1990) Mise en Oeuvre, traitement et présentation du profil plaine du PoMassif Central. In: Roure F et al. (eds) Deep structure of the Alps. Mem Soc Geol Fr 165, pp 65-76

Debelmas J (ed) (1989) Carte Géologique de la France feuille Moûtiers, 1:50000. BRGM

Debelmas J, Kerckhove C (1980) Les Alpes Franco-Italiennes. Geol Alp 56:21-58

Ford M (1996) Kinematics and geometry of early Alpine, basement-involved folds. Eclogae Geol Helv 89:269-295

Freeman SR, Butler RWH, Cliff RA, Inger S, Barnicoat AC (1998) Deformation migration in an orogen-scale shear zone array: an example from the basal Briançonnais thrust, internal Franco-Italian Alps. Geol Mag 135:349-367

Froitzheim N, Schmid SM, Frey M (1996) Mesozoic paleogeography and the timing of eclogite facies metamorphism in the Alps. Eclogae Geol Helv 89:81-110

Fry N (1989) Southwestward thrusting and tectonics of the western Alps. In: Coward MP, Dietrich D, Park RG (eds) Alpine tectonics. Geol Soc Lond Spec Publ 45, pp 83-109

Fügenschuh B, Loprieno A, Ceriani S, Schmid SM (1999) Structural analysis of the Subbriançonnais and Valais units in the area of Moûtiers (Savoy, Western Alps): paleogeographic and tectonic consequences. Int J Earth Sci 88:201-218

Gély J-P (1989) Stratigraphie, tectonique et metamorphisme caompares de part et d'autre du Front Pennique en Tarentaise. $\mathrm{PhD}$ Thesis, Univ Savoie

Gély J-P, Bassias Y (1990) Le Front Pennique: implications structurales d'un métamorphisme transporté (Savoie, France). C R Acad Sci Paris 310:37-43

Gillcrist R, Coward M, Mugnier J-L (1987) Causes et effets de l'inversion structurale: l'exemple de l'avant-pays alpin et des Alpes françaises. Geodinam Acta Paris 1:5-34

Goffé B, Bousquet R (1997) Ferrocarpholite, chloritoid and lawsonite in metapelites of the Versoyen an Petit St. Bernard units (Valais zone, Western Alps). Schweiz Mineral Petrogr Mitt 77:137-147

Goguel J (1963) L'interpretation de l'arc des Alpes occidentales. Bull Soc Geol Fr 7(5):20-33

Grand T (1988) Mesozoic extensional inherited structures on the European margin of the Ligurian Tethys. The example of the Bourg d'Oisan half-graben, western Alps. Bull Soc Geol Fr 8:613-621

Kissling E (1980) Krustenaufbau und Isostasie in der Schweiz. PhD Thesis, ETH Zürich

Laubscher H (1991) The arc of the Western Alps today. Eclogae Geol Helv 84:631-659

Macedo J, Marshak S (1999) Controls on the geometry of foldthrust belt salients. Geol Soc Am Bull 111:1808-1822
Malavieille J, Lacassin R, Mattauer M (1984) Signification tectonique des linéations d'allongement dans les Alpes Occidentales. Bull Soc Geol Fr 7:895-906

Mancktelow N (1985) The Simplon line: a major displacement zone in the western Lepontine Alps. Eclogae Geol Helv 78:73-96

Martinez JR (1980) Contribution a l'étude geologique des alpes occidentales entre Arc et Isere (Région du Mont Nielard et du Cheval Noir) - Savoie - Le problème des unites à flysch. Mémoire de Thèse de Docteur-ingenieur thesis, Univ Pierre et Marie Curie

Martinez JR, Fudral S, Rampnoux JP, Tardy M (1979) Regard sur la stratigraphie du substratum du flysch des Aiguilles d'Arves entre Arc et Isère (Savoie): conséquences paléogeographiques. C R Seances Acad Sci 288:203-206

Masson F, Verdun J, Bayer R, Debeglia N (1999) Une nouvelle carte gravimétrique des Alpes occidentales et ses conséquences structurales et tectoniques. Earth Planet Sci Lett 329:865-871

Maury P, Ricou LE (1983) Le décrochement Subbriançonnais: une nouvelle interprétation de la limite externe-interne des Alpes franco-italiennes. Rev Geogr Phys Geol Dyn 24:3-22

Merle O, Brun JP (1984) The curved translation path of the Parpaillon Nappe (French Alps). J Struct Geol 6:711-719

Mosar J, Stampfli GM, Girod F (1996) Western Préalpes Médianes Romandes: timing and structure. A review. Eclogae Geol Helv 89:389-425

Mugnier JL, Bergerat F, Damotte B, Guellec S, Nicolas A, Polino R, Roure F, Tardy M, Truffert C (1996) Crustal structure of the western Alps and their forelands. Mem Soc Geol Fr 170:73-97

Nicolas A, Polino R, Hirn A, Nicolich R (1990) ECORS-CROP working group. Mem Soc Geol Fr 156:15-27

Perez-Postigo LV (1988) Contribution a l'etude geologique du Subbriançonnais entre Arc et Isère. Les Massifs du Perron des Encombres et de la Grande Moendaz, Alpes Occidentales-Savoie, France. Travaux du departement des sciences de la terre thesis, Univ Savoie

Platt JP, Behrmann JH, Cunningham PC, Dewey JF, Helman M, Parish M, Shepley MG, Wallis S, Weston PJ (1989) Kinematics of the Alpine arc and the motion history of Adria. Nature 337:158-161

Ricou LE, Siddans AWB (1986) Collision tectonics in the western Alps. In: Coward MP, Dietrich D, Park RG (eds) Collision tectonics. Geol Soc Lond Spec Publ 19, pp 229-244

Roure F, Bergerat F, Damotte B, Mugnier J-L, Polino R (1996) The ECORS-CROP Alpine Seismic Traverse. Mem Geol Fr 170:1-113

Schmid SM, Kissling E (2000) The arc of the Western Alps in the light of geophysical data on deep crustal structure. Tectonics 19:62-85

Schmid SM, Pfiffner OA, Froitzheim N, Schönborn G, Kissling E (1996) Geophysical-geological transect and tectonic evolution of the Swiss-Italian Alps. Tectonics 15:1036-1064

Serre A, Toury A, Rampnoux J-P, Martinez-Reyes J, Tardy M (1985) Individualisation de deux unités à flysch nummulitique d'origines paléogéographiques différentes au sein de "l' écaille ultradaphinoise des Aiguilles d' Arves" (région de Saint-Jean de Maurienne, Savoie). C R Acad Sci 301:637-642

Seward D, Mancktelow NS (1994) Neogene kinematics of the central and western Alps: evidence from fission-track dating. Geology 22:803-806

Seward D, Ford M, Bürgisser J, Lickorish H, Williams EA, Meckel III WLD (1999) Preliminary results of fission-track analyses in the Southern Pelvoux area, SE France. Mem Soc Geol 51:25-31

Sinclair HD (1997) Tectonostratigraphic model for underfilled peripheral foreland basins: an Alpine perspective. Geol Soc Am Bull 109:324-346

Spencer S (1992) A kinematic analysis incorporating incremental strain data for the Frontal Pennine Zones of the western French Alps. Tectonophysics 206:285-305 
Stampfli GM, Mosar J, Marquer D, Marchant R, Baudin T, Borel G (1998) Subduction and obduction processes in the Swiss Alps. Tectonophysics 296:159-204

Steck A (1990) Une carte des zones de cisaillement ductile des Alpes Centrales. Eclogae Geol Helv 83:603-626

Sue C, Tricart P (1999) Late Alpine brittle extension above the Frontal Pennine Thrust near Briançon, Western Alps. Eclogae Geol Helv 92:171-181

Sue C, Thouvenot F, Fréchet J, Tricart P (1999) Widespread extension in the core of the western Alps revealed by earthquake analysis. J Geophys Res 104:25611-25622

Thouvenot F, Senechal G, Truffert C, Guellec S (1996) Comparison between two techniques of line-drawing migration (ray tracing and common tangent method). Mem Soc Geol Fr 170:53-59
Tricart P (1986) Le chevauchement de la zone briançonnaise au Sud-Est du Pelvoux: lé des rapports zone externe-zone internes dans les Alpes occidentales. Bull Soc Geol Fr $8: 233-244$

Vialon P, Rochette R, Ménard G (1989) Southwestward thrusting and tectonics of the western Alps. In: Coward MP, Dietrich D, Park RG (eds) Alpine tectonics. Geol Soc Lond Spec Publ 45, pp 329-338

Yamada R, Tagami T, Nishimura S, Ito H (1995) Annealing kinetics of fission track in zircon: an experimental study. Chem Geol (Iso Geosci Sect) 122:249-258 